\title{
Preparation of beta-carotene nanoemulsion and evaluation of stability at a long storage period
}

\author{
Juliana Botelho MOREIRA ${ }^{1}$, Pâmela Guder GOULARTE², Michele Greque de MORAIS ${ }^{1}$, \\ Jorge Alberto Vieira COSTA ${ }^{2 *}$ (D)
}

\begin{abstract}
Carotenoids have a low solubility in water, and therefore their incorporation in foods is impaired. The nanoemulsions are able to protect these compounds and enhance bioavailability. The objective of this study was to develop nanoemulsions with added beta-carotene, evaluating the influence of process variables and the stability at a long storage period. To assess the effects of these variables a Box-Behnken design was performed. The best condition to form a stable emulsion was $7 \%\left(\mathrm{w} . \mathrm{w}^{-1}\right)$ of surfactant and $40^{\circ} \mathrm{C}$. All formulations subjected to a thermal stress test remained stable after the test. The use of a higher concentration of soy lecithin $\left(7 \%, w^{-1}\right)$ in the development of emulsions conferred greater stability after a freeze-defrost cycle. Furthermore, with this concentration of surfactant, and using a high-speed homogenizer under conditions of $10,000 \mathrm{rpm}, 30{ }^{\circ} \mathrm{C}$, and 20 min of shaking time, it was possible to develop stable nanoemulsion with an average diameter of $429 \mathrm{~nm}$. Moreover, the zeta potential indicated system stability. Thus, it was possible to obtain stable nanoemulsion without the use of subsequent equipment, which makes the process less expensive.
\end{abstract}

Keywords: carotenoids; macroscopic evaluation; mean diameter; nanotechnology.

Practical Application: Beta-carotene nanoemulsions developed indicated system stability even after prolonged storage.

\section{Introduction}

Antioxidants are bioactive compounds added to food, which act in the body by different mechanisms. Among these, the complexing metal ions, captured free radicals, peroxide decomposition, inhibition of enzymes responsible for the generation of reactive oxygen and nitrogen species, and the modulation of cell signaling pathways are highlighted (Vasconcelos et al., 2006). Studies show that antioxidants can reduce the incidence of chronic diseases (Xu et al., 2017; Cacciatore, et al., 2018; Singh et al., 2019).

Carotenoids, such as beta-carotene, are natural antioxidants found in fruits, vegetables, and microalgae. Potential health benefits are associated with these compounds, such as reducing the risk of cancer, cardiovascular disease, macular degeneration-related with age, and cataracts (Linnewiel-Hermoni et al., 2015; Liang et al., 2018). Beta-carotene is a long hydrophobic molecule with a high melting point what leads to an extremely low water-solubility and a limited oil-solubility at room temperature. Therefore, incorporate it into aqueous-based foods is challenging, and tends to have a low and variable oral bioavailability (Luo et al., 2017). These antioxidants are generally added to foods in the form of a colloidal system, as nanoemulsions (Qian et al., 2012b; Mehmood et al., 2018).

The emulsion-based systems are suitable for encapsulating (McClements, 2010; McClements \& Xiao, 2012), solubilizing, and transporting the lipophilic bioactive components such as beta-carotene, to the cells of the epithelium where they are absorbed. The lipid digestion phase is identified as a fundamental step to ensure absorption of ingested carotenoids (Furr \& Clark, 1997). Moreover, encapsulation in nanoemulsions enhances the bioavailability of a compound as it reduces the droplet size (Wang et al., 2012; Salvia-Trujillo et al., 2015).

The physicochemical properties and stability of nanoemulsions are influenced by the process conditions (McClements, 2011; Silva et al., 2015). In a stable system, the globules dispersed in nanoemulsions maintain their initial characteristics and remain uniformly distributed by a continuous phase (Chung \& McClements, 2018). Thus, surfactant concentration, speed and time of agitation, temperature, type of oil, and the ratio of water and the oil phase are variables that affect the droplet size and thus should be studied to obtain stable nanoemulsions.

Given the above, the objective of this study was to develop nanoemulsions with added beta-carotene, evaluating the influence of process variables and the stability at a long storage period.

\section{Materials and methods}

\subsection{Experimental design}

To evaluate the effect of surfactant concentration, emulsification temperature and stirring speed in the development of nanoemulsions a Box-Behnken design was performed, varying the concentration of the surfactant $\left(3,5\right.$ and $\left.7 \%, w^{-1} \mathrm{w}^{-1}\right)$, stirring speed $(4,000 ; 7,000$ and $10,000 \mathrm{rpm})$, and emulsification

${ }^{1}$ Laboratório de Microbiologia e Bioquímica, Escola de Química e Alimentos, Universidade Federal do Rio Grande - FURG, Rio Grande, RS, Brasil

${ }^{2}$ Laboratório de Engenharia Bioquímica, Escola de Química e Alimentos, Universidade Federal do Rio Grande - FURG, Rio Grande, RS, Brasil

*Corresponding author: jorgealbertovc@terra.com.br 
temperature $\left(20,30\right.$ and $\left.40{ }^{\circ} \mathrm{C}\right)$, for a total of 15 experiments (Table 1). The results obtained from the experimental data were evaluated using the formed emulsion (a scale was created from 0 to 1 to identify the formation of emulsions), and an analysis of variance (ANOVA), with a confidence level of $90 \%(\mathrm{p} \leq 0.1)$.

\subsection{Preparation of emulsions}

In the development of the emulsion, $0.05 \%\left(\mathrm{w} . \mathrm{w}^{-1}\right)$ of beta-carotene (Delaware) was used from the total volume and the relationship of the oily and aqueous phase 2:8 was analyzed, respectively. The aqueous phase consisted of distilled water. The aqueous phase consisted of distilled water. The surfactant used was soy lecithin powder (Cargill). The concentration of lecithin that was used was based on the total volume of the emulsion. The aqueous and oil phases were heated separately for subsequent stirring for $5 \mathrm{~min}$ at high-speed homogenizer (Ultra-Turrax T25, IKA, Germany). After the preparation, the emulsions were stored in amber glass bottles with a screw cap at $4{ }^{\circ} \mathrm{C}$.

\subsection{Stability evaluation of nanoemulsions}

\subsubsection{Macroscopic evaluation}

Macroscopic analysis of the emulsions was performed $24 \mathrm{~h}$ after preparation (Rocha-Filho et al., 2014). In order to avoid possible instability processes (creaming or phase separation), macroscopic and homogeneity characteristics were observed.

\subsubsection{Freeze-defrost cycle}

The freeze-defrost cycle test was performed according to ANVISA (Agência Nacional de Vigilância Sanitária, 2004) with changes in temperature. The nanoemulsions were subjected to at

Table 1. Actual levels and coding of variables of surfactant concentration $\left(\mathrm{X}_{1}\right)$, stirring speed $\left(\mathrm{X}_{2}\right)$ and emulsification temperature $\left(\mathrm{X}_{3}\right)$ used for the development of nanoemulsions.

\begin{tabular}{ccccc}
\hline Experiment & $\mathrm{X}_{1}\left(\%,{\left.\mathrm{w} \cdot \mathrm{w}^{-1}\right)} \mathrm{X}_{2}(\mathrm{rpm})\right.$ & $\mathrm{X}_{3}\left({ }^{\circ} \mathrm{C}\right)$ & $\mathrm{X}_{4}$ \\
\hline 1 & $3(-1)$ & $4,000(-1)$ & $30(0)$ & 1 \\
2 & $7(+1)$ & $4,000(-1)$ & $30(0)$ & 1 \\
3 & $3(-1)$ & $10,000(+1)$ & $30(0)$ & 0.5 \\
4 & $7(+1)$ & $10,000(+1)$ & $30(0)$ & 1 \\
5 & $3(-1)$ & $7,000(0)$ & $20(-1)$ & 0 \\
6 & $7(+1)$ & $7,000(0)$ & $20(-1)$ & 0 \\
7 & $3(-1)$ & $7,000(0)$ & $40(+1)$ & 0.5 \\
8 & $7(+1)$ & $7,000(0)$ & $40(+1)$ & 1 \\
9 & $5(0)$ & $4,000(-1)$ & $20(-1)$ & 0 \\
10 & $5(0)$ & $10,000(+1)$ & $20(-1)$ & 0 \\
11 & $5(0)$ & $4,000(-1)$ & $40(+1)$ & 1 \\
12 & $5(0)$ & $10,000(+1)$ & $40(+1)$ & 0.5 \\
13 & $5(0)$ & $7,000(0)$ & $30(0)$ & 0.5 \\
14 & $5(0)$ & $7,000(0)$ & $30(0)$ & 0.6 \\
15 & $5(0)$ & $7,000(0)$ & $30(0)$ & 0.4
\end{tabular}

$\mathrm{X}_{1}$ : surfactant concentration; $\mathrm{X}_{2}$ : Stirring speed; $\mathrm{X}_{3}$ : Emulsification temperature; $\mathrm{X}_{4}$ - Scale response of beta-carotene emulsions obtaining: 1 - A stable emulsion was formed; 0.6 - Beta-carotene solubilized but formed an emulsion with a subsequent phase separation; 0.5 - An unstable emulsion was formed; 0.4 - Beta-carotene was solubilized, but did not form an emulsion; 0 - No formed emulsion and beta-carotene was not solubilized.
$30 \pm 2{ }^{\circ} \mathrm{C}$ for $24 \mathrm{~h}$ and after $4 \pm 2{ }^{\circ} \mathrm{C}$ for $24 \mathrm{~h}$, completing a cycle. Samples were macroscopically evaluated $24 \mathrm{~h}$ after preparation and at the end of the 6th cycle (12th day).

\subsubsection{Thermal stress}

The emulsions were subjected to heating $\left(20 \pm 2{ }^{\circ} \mathrm{C}\right.$ to $50 \pm 2{ }^{\circ} \mathrm{C}$ ), where the temperature was raised $10^{\circ} \mathrm{C}$ every $30 \mathrm{~min}$. At each temperature increase and at the end of $50 \pm 2{ }^{\circ} \mathrm{C}$ the formulations were evaluated macroscopically, observing if there was instability on the system as creaming or phase separation.

\subsection{Size of emulsion globules}

The particle size distribution of the emulsions was evaluated in two steps. For the first one, the average diameter $\left(\mathrm{D}_{\text {mean }}\right)$ and polydispersity index (PDI) of stable emulsions were analyzed by dynamic light scattering (DLS) using a Brookhaven Instruments standard setup (BI-200M goniometer, BI-9000 AT digital correlator, EUA) with a vertically polarized Coherent $\mathrm{He}-\mathrm{Ne}$ laser $(\lambda 0=632.8 \mathrm{~nm})$ as light source, at $24^{\circ} \mathrm{C}$. The samples were filtered through $0.45 \mathrm{~nm}$ pore diameter membranes (Millipore) into dust-free vials, which were placed in a cell containing decahydronaphthalene (Aldrich).

At the end of the tests, the emulsion with a lower $\mathrm{D}_{\text {mean }}$ and a lower PDI was developed and analyzed again after preparation (control test) and a long storage period (4 years) compared to DLS via other equipment (Zetasizer Nano ZS-90, Malvern Instruments, Worcestershire, UK), evaluating also the zeta potential. In both analyses, the samples were diluted in MilliQ water; however, in the first analysis, the samples were subjected to filtration $(0.45 \mu \mathrm{m})$.

\section{Results and discussion}

\subsection{Factorial design}

According to the Box-Behnken design and the tests carried out, beta-carotene emulsions were formed (Table 1).

In order to obtain emulsions with beta-carotene, the linear effects of surfactant concentration and the temperature were significant and positive in the maximum levels of each variable as can be observed in Figure 1.

Thus, it was found that the increase in the values of these parameters improved the stability of emulsions. Furthermore, it was observed that the emulsification temperature was the variable with the largest effect on obtaining the emulsions (Table 2), proving to be the most influential parameter in the process.

According to Santos et al. (2014), heating promotes the reduction of oil viscosity and consequently decreases the cohesive forces between the molecules. This facilitates solubilization in the oil bicontinuous phase, forming more stable emulsions.

Oliveira (2008) developed nanoemulsions with andiroba (Carapa guianensis) oil and Ultroil R400/Span 80 surfactants and it was observed that, at $25^{\circ} \mathrm{C}$, creaming and lightweight phase separation occurred; and between $35-45{ }^{\circ} \mathrm{C}$ the formulations were macroscopically stable. In the formulation with a $3 \%\left(\mathrm{w} \cdot \mathrm{w}^{-1}\right)$ surfactant, there was a phase separation within $24 \mathrm{~h}$ after emulsion 
preparation. However, the emulsions prepared with 4 to $8 \%\left(\mathrm{w} \cdot \mathrm{w}^{-1}\right)$ showed no macroscopic signs of instability. Thus, the authors found that better emulsions were obtained from higher surfactant concentration as observed in the present study with the use of sunflower oil, soy lecithin, and beta-carotene. Bernardi et al. (2011) also assessed the concentration of surfactant and found that $5 \%\left(\mathrm{w} \cdot \mathrm{w}^{-1}\right)$ was not enough to form the nanoemulsion.

Regarding the linear effect of stirring speed, it was significant and negative (Figure 2). Thus, reducing the value of this parameter facilitates the formation of the emulsion. According to Rocha-Filho et al. (2014), agitation speed is considered a critical parameter due to the high fluidity of the system of nanoemulsions that requires no collision barriers compared with the emulsions with higher viscosity.

\subsection{Evaluation of the stability of emulsions}

Initially, the developed emulsions were evaluated macroscopically, and a milky characteristic was observed. The macroscopic analysis was performed $24 \mathrm{~h}$ after the preparation, once the emulsion

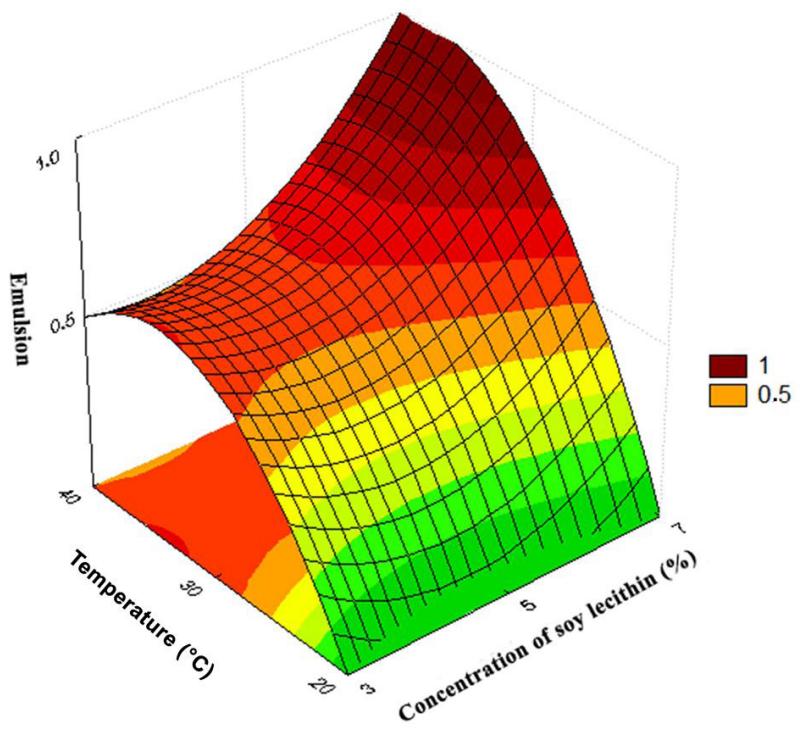

Figure 1. Response surface plot and coutorn lines to obtain beta-carotene nanoemulsions as a function of lecithin concentration and emulsification temperature. could not be completely balanced during development; and this could be explained when one considers the intrinsic instability of emulsions. Therefore, it is desirable to wait for an initial period of stabilization (Rocha-Filho et al., 2014).

Emulsions presented an orange color, with the exception of formulations developed at $20^{\circ} \mathrm{C}$ (experiments 5, 6, 9 and 10), because there was no solubilization of the beta-carotene. Therefore, these samples were ignored as stability tests. According to Qian et al. (2012a), the development process of the nanoemulsions is generally performed at elevated temperatures to avoid crystallization of the carotenoids during the preparation of the emulsion. However, it is important to take care to prevent the chemical degradation of the active component in the process.

All formulations subjected to a thermal stress test remained macroscopically stable after the three temperature elevations. According to Lachman et al. (1986), the colorants may change the physical properties of the emulsions and hence are added at lower temperatures $\left(45-50{ }^{\circ} \mathrm{C}\right)$. The formulations were subjected to a thermal stress test and to a preliminary stability

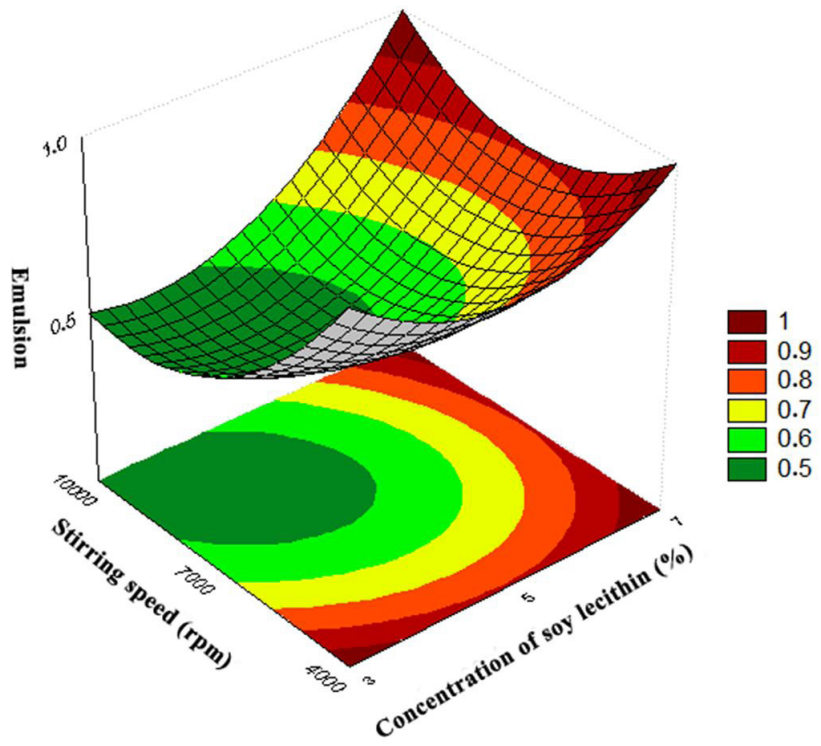

Figure 2. Response surface plot and contour lines to obtain beta-carotene nanoemulsions as a function of the stirring speed and lecithin concentration.

Table 2. Statistical significances and effects obtained from the analysis of the factorial design used for the preparation of beta-carotene emulsions.

\begin{tabular}{|c|c|c|c|c|}
\hline \multirow{2}{*}{ Factor } & \multicolumn{4}{|c|}{ Emulsions } \\
\hline & Effect & Standard error & $\mathrm{T}(2)$ & $P$ \\
\hline $\mathrm{X}_{1}(\mathrm{~L})$ & 0.25 & 0.071 & 3.535 & $0.071^{*}$ \\
\hline $\mathrm{X}_{1}(\mathrm{Q})$ & -0.19 & 0.052 & -3.603 & $0.069^{*}$ \\
\hline $\mathrm{X}_{2}(\mathrm{~L})$ & -0.25 & 0.071 & -3.535 & $0.071^{*}$ \\
\hline $\mathrm{X}_{2}(\mathrm{Q})$ & -0.19 & 0.052 & -3.602 & $0.069^{*}$ \\
\hline $\mathrm{X}_{3}(\mathrm{~L})$ & 0.75 & 0.071 & 10.607 & $0.008^{*}$ \\
\hline $\mathrm{X}_{3}(\mathrm{Q})$ & 0.31 & 0.052 & 6.004 & $0.026^{*}$ \\
\hline $\mathrm{X}_{1 .} \mathrm{X}_{2}$ & 0.25 & 0.100 & 2.500 & 0.129 \\
\hline $\mathrm{X}_{1} \mathrm{X}_{3}$ & 0.25 & 0.100 & 2.500 & 0.129 \\
\hline $\mathrm{X}_{2 .} \mathrm{X}_{3}$ & -0.25 & 0.100 & -2.500 & 0.129 \\
\hline
\end{tabular}

$\mathrm{X}_{1}$ : surfactant concentration; $\mathrm{X}_{2}$ : Stirring speed; $\mathrm{X}_{3}$ : Temperature emulsification; L: linear effect; Q: quadratic effect; ${ }^{*}$ statistically significant at $90 \%$ confidence interval. 
test known as the freeze-defrost cycle. The principle of this test is to evaluate the stability of the samples against sudden temperature changes. Formulations 3 and 7 were developed with the lower concentration of soy lecithin $\left(3 \%, \mathrm{w} \cdot \mathrm{w}^{-1}\right)$; and after $3 \mathrm{~d}$ of experiment they showed instability characteristics at the end of the freeze-defrost assay. The beta-carotene emulsions that remained stable macroscopically after the test were those of experiments in these conditions: at $30^{\circ} \mathrm{C}, 3 \%\left(\mathrm{w} \cdot \mathrm{w}^{-1}\right)$ of lecithin and $4,000 \mathrm{rpm} ; 30^{\circ} \mathrm{C}, 7 \%\left(\mathrm{w} \cdot \mathrm{w}^{-1}\right)$ of lecithin and $4,000 \mathrm{rpm}$; $30{ }^{\circ} \mathrm{C}, 7 \%\left(\right.$ w. $\left.\mathrm{w}^{-1}\right)$ of lecithin and $10,000 \mathrm{rpm} ; 40^{\circ} \mathrm{C}, 7 \%\left(\mathrm{w} \cdot \mathrm{w}^{-1}\right)$ of lecithin and 7,000 rpm; and $40^{\circ} \mathrm{C}, 5 \%\left(\mathrm{w}^{-1} \mathrm{w}^{-1}\right)$ of lecithin and 4,000 rpm (experiment 1, 2, 4, 8 and 11, respectively).

According to macroscopic evaluation, it was found that in experiments at $30{ }^{\circ} \mathrm{C}, 5 \%\left(\mathrm{w} \cdot \mathrm{w}^{-1}\right)$ of lecithin and 7,000 rpm the stability cycle freeze-defrost test caused instability in the system, influencing the emulsion color. Due to the high rate of unsaturation, heat, light, and acids cause isomerization of the trans carotenoid which is the most stable form to the cis form, causing the loss of color of the emulsion. Carotenoids are also susceptible to non-enzymatic or enzymatic oxidations that depend on the carotenoid structure, oxygen availability, presence of enzymes, high temperature, and exposure to light (Rodriguez-Amaya, 1999).

\subsection{Average diameter of emulsions}

The emulsion showed a lower $\mathrm{D}_{\text {mean }}$ and PDI when the highest concentration of soy lecithin $\left(7 \%\right.$, w. $\left.\mathrm{w}^{-1}\right)$, a higher stirring speed $\left(10,000 \mathrm{rpm}\right.$ ), and the emulsification temperature at $30^{\circ} \mathrm{C}$ (Table 3 ) were used. Monitoring the physical stability of nanoemulsions can be performed by monitoring the size and polydispersion of the nanoparticles (Bernardi et al., 2011). According to Fernandez et al. (2004), PDI is an important parameter, because the higher the value, the faster the processes of instability will happen, as the diameter of the globules increases.

According to McClements (2015), agitation with a high speed facilitates the oil solubilization during the emulsification process, which explains the smaller diameter obtained for the nanoemulsion developed at $10,000 \mathrm{rpm}$. Regarding the concentration of the surfactant, this variable affects the size of globules and consequently the emulsion stability (Silva et al., 2015; Bernardi et al., 2011). High surfactant concentrations

Table 3. Average diameter $\left(\mathrm{D}_{\text {mean }}\right)$ and polydispersity index (PDI) of beta-carotene emulsions after $48 \mathrm{~h}$ of preparation.

\begin{tabular}{ccc}
\hline Experiment & $\mathrm{D}_{\text {mean }}(\mathrm{nm})$ & PDI \\
\hline 5 min agitation & & \\
2 & $746.4 \pm 11.7$ & $0.55 \pm 0.08$ \\
4 & $691.9 \pm 71.5$ & $0.40 \pm 0.001$ \\
8 & $714.0 \pm 43.5$ & $0.42 \pm 0.06$ \\
11 & $868.3 \pm 46.1$ & $0.52 \pm 0.01$ \\
10 min agitation & \\
4 & $642.6 \pm 30.7$ & $0.41 \pm 0.02$ \\
20 min agitation & \\
4 & $429.0 \pm 22.7$ & $0.40 \pm 0.01$ \\
\hline Results are averages of three determinations \pm the standard deviations.
\end{tabular}

cause an increased interfacial area while reducing the interfacial tension, resulting in smaller droplet size (Pengon et al., 2018). Rocha-Filho et al. (2014) also observed a reduction in the particle size distribution increasing the surfactant concentration.

Thus, the emulsion that showed the lower $\mathrm{D}_{\text {mean }}$ after $48 \mathrm{~h}$ of preparation (assay 4 ) was prepared again increasing the agitation time to $20 \mathrm{~min}$, and it was found that $\mathrm{D}_{\text {mean }}$ of the emulsion globules decreased. The beta-carotene emulsions developed with Ultra-Turrax, at $30^{\circ} \mathrm{C}$, a stirring speed of $10,000 \mathrm{rpm}$, and a surfactant concentration of $7 \%\left(\mathrm{w} \cdot \mathrm{w}^{-1}\right)$ and 5 min of stirring resulted in a $\mathrm{D}_{\text {mean }}$ of emulsions of approximately $755 \mathrm{~nm}$. When increasing the stirring time for $20 \mathrm{~min}$ it was possible to obtain beta-carotene nanoemulsions with a $\mathrm{D}_{\text {mean }}$ less than $500 \mathrm{~nm}$. The higher stirring time may have favored the distribution of emulsifier in the oil phase and favored the solubilization of emulsifier in the bicontinuous phase, resulting in smaller globules.

The obtaining of nanoemulsions through the use of high-pressure homogenizers and microfluidizers has been described in the literature (Singh et al., 2017; Salvia-Trujillo et al., 2015; Lee \& Norton, 2013). The preparation of the nanoemulsions by these procedures can be divided into two distinct phases. In the first step, the oily and aqueous phases are heated separately and emulsified through the use of the high-speed homogenizers, such as an Ultra-Turrax. The emulsion obtained in the first step has a droplet size between 500 and 1,000 $\mathrm{nm}$ influenced by the equipment and operating conditions. In the second step, the droplet diameter is progressively reduced to values between 100-300 nm through high-pressure homogenizers (Peng et al., 2018; Primozic et al., 2018) and microfluidizers (Luo et al., 2017).

The nanoemulsion developed at $30{ }^{\circ} \mathrm{C}, 10,000 \mathrm{rpm}$ and $7 \%\left(\right.$ w. $\left.\mathrm{w}^{-1}\right)$ of surfactant remained without any evidence of creaming and/or phase separation after four years of preparation. However, over this period, with the increase of PDI and $\mathrm{D}_{\text {mean, }}$ the nanoemulsion was 61.4 and $30.3 \%$ compared with the control, respectively.

The emulsification process is complex and may or may not cause coalescence. In the initial agitation time, the formation of the disperse phase is observed. However, there is an increased collision of particles and the possibility of coalescence as stirring is continued. The reasons for the stabilization phenomenon of globules are dependent upon the stirring speed and time and can be attributed to the distribution of the emulsifier between the phases. The slow formation of interfacial film or interruption of the film formation by continuous stirring contributes to the stability (Singh et al., 2019; Chung \& McClements, 2018; Lachman et al., 1986). In addition, according to Rocha-Filho et al. (2014), there is an increase in the formation of micelles in systems where the surfactants are in excess, which can facilitate mass transport of oil molecules into larger globules, resulting in increased particle size as a function of time.

The zeta potential is an indication of the repulsive forces between the oil droplets of an emulsion. This parameter characterizes the emulsion's ability of coalescing/flocculation and reflects its stability (Kumar et al., 2013). High zeta potential values (positive or negative) indicate the difficulty of droplets coalescing and high emulsion stability. The corresponded range to 
the zeta potential of the emulsions developed with beta-carotene $(-39.0 \pm 1.5$ to control and $-57.2 \pm 1.5$ after 4 years $)$ indicated a system stability even after prolonged storage.

\section{Conclusion}

Among the variables studied in the development of beta-carotene emulsions, the temperature had the highest effect (significant and positive) showing that with the increasing of temperature formed more stable emulsions. The stable beta-carotene nanoemulsion was obtained with high concentrations of soy lecithin $\left(7 \%\right.$, w. $\left.\mathrm{w}^{-1}\right)$ and agitation speed $(10,000 \mathrm{rpm})$, at $30^{\circ} \mathrm{C}$. When increasing the stirring time of 5 to $20 \mathrm{~min}$, there was a reduction (38\%) of the average diameter of the nanoemulsion, resulting in $429.0 \mathrm{~nm}$. Although it has been observed an increase in $\mathrm{D}_{\text {mean }}(61.4 \%)$ and PDI (30.3\%) after 4 years of storage, the nanoemulsion remained without signs of creaming or phase separation. Moreover, the zeta potential of the nanoemulsion developed indicated system stability.

In addition, the preparation process presented in this paper dispensed with using high-pressure homogenizers or microfluidizers, making the process less expensive and therefore economically feasible.

\section{References}

Agência Nacional de Vigilância Sanitária - ANVISA. (2004). Guia de estabilidade de produtos cosméticos. Brasília: ANVISA.

Bernardi, D. S., Pereira, T. A., Maciel, N. R., Bortoloto, J., Viera, G. S., Oliveira, G. C., \& Rocha-Filho, P. A.. (2011). Formation and stability of oil-in-water nanoemulsions containing rice bran oil: in vitro and in vivo assessments. Journal of Nanobiotechnology, 9(1), 1-9. http:// dx.doi.org/10.1186/1477-3155-9-44. PMid:21952107.

Cacciatore, I., Marinelli, L., Di Stefano, A., Di Marco, V., Orlando, G., Gabriele, M., Gatta, D. M. P., Ferrone, A., Franceschelli, S., Speranza, L., \& Patruno, A. (2018). Chelating and antioxidant properties of L-Dopa containing tetrapeptide for the treatment of neurodegenerative diseases. Neuropeptides, 71, 11-20. http://dx.doi. org/10.1016/j.npep.2018.06.002. PMid:29937392.

Chung, C., \& McClements, D. J. (2018). Characterization of physicochemical properties of nanoemulsions: appearance, stability, and rheology. In S. M. Jafari, \& D. J. McClements (Eds.), Nanoemulsions formulation, applications, and characterization (Cap. 17, pp. 546-602). San Diego: Academic Press. http://dx.doi.org/10.1016/B978-0-12-8118382.00017-5.

Fernandez, P., André, V., Rieger, J., \& Kühnle, A. (2004). Nano-emulsion formation by emulsion phase inversion. Colloids and Surfaces. A, Physicochemical and Engineering Aspects, 251(1-3), 53-58. http:// dx.doi.org/10.1016/j.colsurfa.2004.09.029.

Furr, H. C., \& Clark, R. M. (1997). Intestinal absorption and tissue distribution of carotenoids. The Journal of Nutritional Biochemistry, 8(7), 364-377. http://dx.doi.org/10.1016/S0955-2863(97)00060-0.

Kumar, P., Mishra, S., Malik, A., \& Satya, S. (2013). Preparation and characterization of Menthax piperita oil emulsion for housefly (Musca domestica L.) control. Industrial Crops and Products, 44, 611-617. http://dx.doi.org/10.1016/j.indcrop.2012.09.013.

Lachman, L., Lierberman, H. A., \& Kanig, J. L. (1986). The theory and practice of industrial pharmacy (3rd ed.) Philadelphia: Lea \& Febiger.

Lee, L., \& Norton, I. T. (2013). Comparing droplet breakup for a highpressure valve homogeniser and a microfluidizer for the potential production of food-grade nanoemulsions. Journal of Food Engineering, 114(2), 158-163. http://dx.doi.org/10.1016/j.jfoodeng.2012.08.009.

Liang, R., Huang, Q., Ma, J., Shoemaker, C. F., \& Zhong, F. (2018). Effect of relative humidity on the store stability of spray-dried betacarotene nanoemulsions. Food Hydrocolloids, 33(2), 225-233. http://dx.doi. org/10.1016/j.foodhyd.2013.03.015.

Linnewiel-Hermoni, K., Khanin, M., Danilenko, M., Zango, G., Amosi, Y., Levy, J., \& Sharoni, Y. (2015). The anti-cancer effects of carotenoids and other phytonutrients resides in their combined activity. Archives of Biochemistry and Biophysics, 572, 28-35. http:// dx.doi.org/10.1016/j.abb.2015.02.018. PMid:25711533.

Luo, X., Zhou, Y., Bai, L., Liu, F., Deng, Y., \& McClements, D. J. (2017). Fabrication of $\beta$-carotene nanoemulsion-based delivery systems using dual-channel microfluidization: physical and chemical stability. Journal of Colloid and Interface Science, 490, 328-335. http://dx.doi. org/10.1016/j.jcis.2016.11.057. PMid:27914331.

McClements, D. J. (2010). Emulsion design to improve the delivery of functional lipophilic components. Annual Review of Food Science and Technology, 1(1), 241-269. http://dx.doi.org/10.1146/annurev. food.080708.100722. PMid:22129337.

McClements, D. J. (2011). Edible nanoemulsions: fabrication, properties, and functional performance. Soft Matter, 7(6), 2297-2316. http:// dx.doi.org/10.1039/C0SM00549E.

McClements, D. J., \& Xiao, H. (2012). Potential biological fate of ingested nanoemulsions: influence of particle characteristics. Food \& Function, 3(3), 202-220. http://dx.doi.org/10.1039/C1FO10193E. PMid:22105669.

McClements, D. J. (2015). Food emulsions food emulsions: principles, practices, and techniques (3th ed.). Boca Raton: CRC Press. http:// dx.doi.org/10.1201/b18868.

Mehmood, T., Ahmed, A., Ahmad, A., Ahmad, M. S., \& Sandhu, M. A. (2018). Optimization of mixed surfactants-based $\beta$-carotene nanoemulsions using response surface methodology: an ultrasonic homogenization approach. Food Chemistry, 253, 179-184. http:// dx.doi.org/10.1016/j.foodchem.2018.01.136. PMid:29502819.

Oliveira, B. R. (2008). Desenvolvimento e avaliação de nanoemulsões com óleos de Carapa guianensis e Copaifera sp. e estudo da ação repelente frente a Aedes aegypti (Dissertação de mestrado). Universidade de São Paulo, São Paulo.

Peng, Y., Meng, Q., Zhou, J., Chen, B., Xi, J., Long, P., Zhang, L., \& Hou, R. (2018). Nanoemulsion delivery system of tea polyphenols enhanced the bioavailability of catechins in rats. Food Chemistry, 242, 527-532. http://dx.doi.org/10.1016/j.foodchem.2017.09.094. PMid:29037724.

Pengon, S., Chinatangkul, N., Limmatvapirat, C., \& Limmatvapirat, S. (2018). The effect of surfactant on the physical properties of coconut oil nanoemulsions. Asian Journal of Pharmaceutical Sciences, 13(5), 409-414. http://dx.doi.org/10.1016/j.ajps.2018.02.005.

Primozic, M., Duchek, A., Nickerson, M., \& Ghosh, S. (2018). Formation, stability and in vitro digestibility of nanoemulsions stabilized by highpressure homogenized lentil proteins isolate. Food Hydrocolloids, 77, 126-141. http://dx.doi.org/10.1016/j.foodhyd.2017.09.028.

Qian, C., Decker, E. A., Xiao, H., \& McClements, D. J. (2012a). Inhibition of $\beta$-carotene degradation in oil-in-water nanoemulsions: influence of oil-soluble and water-soluble antioxidants. Food Chemistry, 135(3), 1036-1043. http://dx.doi.org/10.1016/j.foodchem.2012.05.085. PMid:22953821.

Qian, C., Decker, E. A., Xiao, H., \& McClements, D. J. (2012b). Physical and chemical stability of b-carotene-enriched nanoemulsions: Influence of $\mathrm{pH}$, ionic strength, temperature, and emulsifier type. Food Chemistry, 132(3), 1221-1229. http://dx.doi.org/10.1016/j. foodchem.2011.11.091. PMid:29243604. 
Rocha-Filho, P. A., Camargo, M. F. P., Ferrari, M., \& Maruno, M. (2014). Influence of Lavander Essential Oil Addition on Passion Fruit Oil Nanoemulsions: Stability and In vivo Study. Journal of Nanomedicine \& Nanotechnology, 5, 1-11.

Rodriguez-Amaya, D. B. (1999). Changes in carotenoids during processing and storage of foods. Archivos Latinoamericanos de Nutricion, 49(3, Suppl 1), 38S-47S. PMid:10971842.

Salvia-Trujillo, L. S., Sun, Q., Um, B. H., Park, Y., \& McClements, D. J. (2015). In vitro and in vivo study of fucoxanthin bioavailability from nanoemulsion-based delivery systems: Impact of lipid carrier type. Journal of Functional Foods, 17, 293-304. http://dx.doi.org/10.1016/j. jff.2015.05.035.

Santos, R. G., Loh, W., Bannwart, A. C., \& Trevisan, O. V. (2014). An overview of heavy oil properties and its recovery and transportation methods. Brazilian Journal of Chemical Engineering, 31(3), 571-590. http://dx.doi.org/10.1590/0104-6632.20140313s00001853.

Silva, H. D., Cerqueira, M. A., \& Vicente, A. A. (2015). Influence of surfactant and processing conditions in the stability of oil-in-water nanoemulsions. Journal of Food Engineering, 167, 89-98. http:// dx.doi.org/10.1016/j.jfoodeng.2015.07.037.
Singh, Y. P., Girisa, S., Banik, K., Ghosh, S., Swathi, P., Deka, M., Padmavathi, G., Kotoky, J., Sethi, G., Fan, L., Mao, X., Halim, E., Arfuso, F., \& Kunnumakkara, A. B. (2019). Potential application of zerumbone in the prevention and therapy of chronic human diseases. Journal of Functional Foods, 53, 248-258. http://dx.doi. org/10.1016/j.jff.2018.12.020.

Singh, Y., Meher, J. G., Raval, K., Khan, F. A., Chaurasia, M., Jain, N. K., \& Chourasia, M. K. (2017). Nanoemulsion: Concepts, development and applications in drug delivery. Journal of Controlled Release, 252, 28-49. http://dx.doi.org/10.1016/j.jconrel.2017.03.008. PMid:28279798.

Vasconcelos, S. M. L., Silva, A. M., \& Goulart, M. O. F. (2006). Próantioxidantes e antioxidantes de baixo peso molecular oriundos da dieta: estrutura e função. Nutrire, 31(3), 95-118.

Wang, P., Liu, H., Mei, X., Nakajima, M., \& Yin, L. (2012). Preliminary study into the factors modulating $\mathrm{b}$-carotene micelle formation in dispersions using an in vitro digestion model. Food Hydrocolloids, 26(2), 427-433. http://dx.doi.org/10.1016/j.foodhyd.2010.11.018.

Xu, Z., Sun, T., Li, W., \& Sun, X. (2017). Inhibiting effects of dietary polyphenols on chronic eye diseases. Journal of Functional Foods, 39, 186-197. http://dx.doi.org/10.1016/j.jff.2017.10.031. 